\title{
Is the Fetal Lung a Mineralocorticoid Receptor Target Organ? Induction of Cortisol-Regulated Genes in the Ovine Fetal Lung, Kidney and Small Intestine
}

\author{
Maureen Keller-Wood Marcela von Reitzenstein Jarret McCartney \\ Department of Pharmacodynamics, University of Florida, Gainesville, Fla., USA
}

Key Words

Cortisol $\cdot$ Aldosterone $\cdot \mathrm{ENaC} \alpha \cdot \mathrm{Na}$, K-ATPase $\cdot$ Fetal lung

\begin{abstract}
Background: Lung, kidney and small intestine are involved in fetal volume regulation and amniotic fluid secretion and play a pivotal role in the transition from intrauterine to extrauterine life. Objective: This study was performed to determine the ontogeny of mineralocorticoid receptors (MR) and glucocorticoid receptors (GR), and of MR- and GR-regulated genes and proteins, serum and glucocorticoid-induced kinase (Sgk-1), epithelial sodium channel ( $\mathrm{ENaC} \alpha)$, and $\mathrm{Na}, \mathrm{K}-$ ATPase $\alpha 1$. Methods: Lung, renal cortex and medulla, and small intestine were collected from fetuses at 80, 100, 120, 130 and 145 days' gestation and from day 1 and 7 neonatal lambs. Real-time PCR was performed to determine mRNA concentration for MR, GR, the 11 $\beta$-hydroxysteroid dehydrogenases (11 $\beta$-HSD1 and 2), Sgk-1, ENaC $\alpha$, and Na,K-ATPase $\alpha 1$. Protein expression of $\mathrm{ENaC} \alpha$ and $\mathrm{Na}, \mathrm{K}-\mathrm{ATP}$ ase $\alpha 1$ in whole cell and membrane fractions was determined by immunoblotting. Results: Expression of corticosteroid-induced genes in renal cortex increases at term; in small intestine the induction occurs postnatally. In contrast, in lung expression of MR and GR mRNAs were greater at 100 days to term than postnatally and $11 \beta-$ HSD1 peaked at 145 days; the corticosteroid-induced genes also increased prenatally: Sgk-1 and $\mathrm{ENaC} \alpha$ increased by 120 days, peaking at 145 days, and $\mathrm{Na}, \mathrm{K}-$ ATPase $\alpha 1$ was greatest at 130 days. Conclusions: The ex-
\end{abstract}

\section{KARGER}

() 2008 S. Karger AG, Base

Fax +41613061234 E-Mail karger@karger.ch www.karger.com
Accessible online at: www.karger.com/neo pression of high levels of MR and $11 \beta-H S D 1$ in preterm fetal lung suggest low endogenous fetal cortisol may exert actions at the high affinity MR in vivo, leading to increases in expression of sodium channels important in the regulation of lung liquid secretion and reabsorption.

Copyright $\odot 2008$ S. Karger AG, Basel

\section{Introduction}

In primates and in sheep, fetal secretion of cortisol increases exponentially before birth. Cortisol induces maturation of organ function and is necessary for the normal transition to extrauterine life. In sheep, the prepartum surge of fetal cortisol induces the conversion of progesterone to estrogen in placenta $[1,2]$. These critical actions of cortisol at the time of birth are exerted primarily by glucocorticoid receptors (GR), and synthetic glucocorticoids such as dexamethasone and betamethasone are well known to induce maturation of surfactant production in the lung $[3,4]$, gluconeogenesis in the liver $[5,6]$, and maturation of the gastrointestinal tract $[7,8]$.

Prior to maturation of the fetal adrenals, the circulating levels of fetal corticosteroids are relatively low (2-4 $\mathrm{ng} / \mathrm{ml}$ in ovine fetuses before 130 days' gestation) and are primarily the consequence of the transplacental passage

Supported by NIH grant DK62080.
Maureen Keller-Wood, PhD

Box 100487, Department of Pharmacodynamics

University of Florida, Gainesville, FL 32610 (USA)

Tel. +1 352392 8798, Fax +1 3522737705

E-Mail kellerwd@cop.ufl.edu 
of small quantities of maternally-derived corticosteroids [9]. Although the placenta expresses $11 \beta$-hydroxysteroid dehydrogenase (11 $\beta$-HSD)2, which limits placental transfer of cortisol, fetal plasma concentrations of cortisol are higher than those of cortisone before term [10]. These low concentrations of cortisol in the fetus would exert only minimal effects via the higher capacity, GR, however the estimated free levels are close to the $K_{d}$ for the high-affinity (corticosteroid type I) mineralocorticoid receptors (MR). Although in rodent species MR are relatively sparse before the last day or two of gestation [11], in human fetuses MR have been found at 16 weeks of gestation [12]. In previous studies we have found evidence of MR in ovine fetal lung by 120 days' gestation [13].

The objective of this study was to determine the ontogeny of MR and GR, and of corticosteroid-regulated genes in three tissues involved in fetal volume regulation and amniotic fluid secretion in late gestation: lung, kidney and small intestine. We also measured the expression of the $11 \beta$-HSD1 and $11 \beta-H S D 2.11 \beta-H S D 1$ functions in vivo primarily as a reductase, converting the inactive 11dehydrosteroid, cortisone, to the active steroid cortisol using NADPH as a co-substrate [14]. In fetal lung, 11 $\beta$ HSD1 activity predominates $[15,16]$, allowing corticosteroids to induce surfactant-phosphatidyl-choline synthesis in type 2 pneumocytes [17]. 11ß-HSD2 enzyme functions as an exclusive dehydrogenase for endogenous cortisol and corticosterone, metabolizing the active 11hydroxysteroids to the inactive 11-ketosteroids [18]. In contrast, $11 \beta$-HSD2 activity predominates in adult and fetal kidney, effectively preventing cortisol, but not aldosterone, action at MR.

We also determined the ontogeny of three genes induced by GR or MR action in epithelia: serum and glucocorticoid-regulated kinase (Sgk-1), the $\alpha$-subunit of the epithelial sodium channel $(\mathrm{ENaC} \alpha)$, and the $\alpha 1$-subunit of the sodium-potassium ATPase (Na,K-ATPase $\alpha 1$ ). These genes are known to be induced by MR action in the adult kidney and to mediate sodium reabsorption in the kidney [19]; these genes also are thought to mediate lung liquid reabsorption at the time of delivery $[20,21]$ and to be involved in fluid flux in the gastrointestinal tract [22]. The expression of $\mathrm{ENaC} \alpha$ is known to be induced by synthetic glucocorticoids in adult lung [23], preterm rabbit lung [24], and cultures of fetal [25,26] or adult lung [27] as well as by exogenous glucocorticoid treatment in fetal rats [28]. Glucocorticoids also induce expression of the $\alpha$ - or $\beta$-subunits of $\mathrm{Na}, \mathrm{K}$-ATPase in cultured fetal lungs $[29,30]$, although maternal glucocorticoid treatment did not induce Na,K-ATPase subunits in fetal rat lung [28]. Gluco- corticoid induction of these genes occurs via transcriptional activation at glucocorticoid response elements at which MR are also able to bind [31,32], and therefore suggest that in the preterm fetal lung both MR as well as GR action might induce expression of these genes. Since MR are higher affinity receptors for cortisol, we would anticipate that induction of these genes might precede the timing of appreciable GR activation at term in tissue with relatively low $11 \beta$-HSD2 expression. Therefore, we hypothesized that we would find tissue-specific expression of MR, GR, both $11 \beta-H S D$ isoforms, and corticosteroid-induced genes in these tissues. We hypothesized that expression of corticosteroid-regulated genes and proteins will be increased earlier in gestation in fetal lung, corresponding to the expression of MR and 11 $\beta-H S D 1$ in this tissue, than in kidney or small intestine, in which $11 \beta-H S D 2$ would be expected to be more abundantly expressed.

\section{Materials and Methods}

\section{Animals}

Tissues were obtained from fetuses of time-dated pregnant ewes between 80 and 145 days' gestation (normal term 148-149 days), or from lambs on the first or second postnatal day or day 7 postnatally. At the time of sacrifice, ewes were housed in individual pens in rooms with controlled light (12/12 h light/dark cycle), humidity $(<50 \%)$ and temperature $\left(20 \pm 1{ }^{\circ} \mathrm{C}\right)$. Ewes were fed daily with alfalfa hay and mixed concentrated feed and water at libitum. All use of animals was approved by the Institutional Animal Care and Use Committee at the University of Florida.

Pregnant ewes were euthanized with $20 \mathrm{ml}$ Euthol solution (7.8 g pentobarbital and $1 \mathrm{~g}$ phenytoin sodium i.v.; Virbac $\mathrm{AH}$, Inc., Fort Worth, Tex., USA) at 80, 96-100, 120, 130 and 143-146 days of gestation, and lambs were euthanized with $3 \mathrm{ml}$ of Euthol on within 48 h of delivery or on day 7 after delivery. None of the ewes at 143-146 days showed any signs of impending labor; this group is hereafter referred to as the ' 145 ' day group. Pieces of fetal and neonatal lung, kidney cortex and medulla and small intestine were rapidly collected, frozen in liquid nitrogen and stored at $-80^{\circ} \mathrm{C}$ until extraction of RNA. All animal use in this study was approved by the Institutional Animal Care and Use Committee of the University of Florida, and performed according to the Guiding Principles for the Care and Use of Animals of the American Physiological Society.

\section{Quantitation by RT-PCR}

To determine the relative abundance of GR, MR, ENaC $\alpha$, Na,K-ATPase $\alpha 1$, Sgk-1, $11 \beta$-HSD1, $11 \beta$-HSD2 and $\beta$-actin mRNA, in tissues from different ages, real-time quantitative PCR was performed. Total RNA was extracted from approximately 250 mg of kidney cortex or medulla and of $200 \mathrm{mg}$ of lung or small intestine with TRIzol (Gibco/BRL, Grand Island, N.Y., USA) following the manufacturer's recommended protocol. Tissues were homogenized in TRIzol and extracted with chloroform $(0.2 \mathrm{ml} /$ $\mathrm{ml}$ TRIzol). Isopropanol $(0.5 \mathrm{ml} / \mathrm{ml}$ TRIzol) was used to precipi- 
tate the RNA from its aqueous phase. RNA was pelleted by centrifugation at 7,500 $\mathrm{g}$ and $4^{\circ} \mathrm{C}$ for $5 \mathrm{~min}$, washed in $75 \%$ ethanol, centrifuged again, air-dried for $10 \mathrm{~min}$ and dissolved in $200 \mu \mathrm{l}$ HPLC water. Total RNA from kidney and small intestine was treated with DNase (Ambion DNA-free ${ }^{\mathrm{TM}}$; Ambion, Inc., Austin, Tex., USA: 2 U/10 $\mu \mathrm{g}$ RNA). Total RNA concentration was determined by spectrophotometry and RNA purity was confirmed by 260:280 ratio and by electrophoresis in a $1 \%$ agarose/ethidium bromide gel. RNA samples were stored thereafter at $-80^{\circ} \mathrm{C}$ until performing real-time RT-PCR. cDNA was subsequently synthesized using a high-capacity cDNA archive kit (Applied Biosystems, Foster City, Calif., USA). cDNA samples were then stored at $-20^{\circ} \mathrm{C}$ until used.

Gene abundance was normalized to $\beta$-actin mRNA, which did not change with age in any of the four tissues tested. The RNA quantity used was optimized to ensure equal efficiency of amplification of mRNA. Primers and probe concentrations were also optimized according to the manufacturer's protocol and the reaction was performed in an ABI Prism 7000 sequence detector (Applied Biosystems). Each sample was performed in triplicate for each gene of interest and $\beta$-actin. PCR primers and TaqMan probes specific for each gene were designed using Primer Express software (Applied Biosystems). 18S rRNA primers and probe were from TaqMan ribosomal RNA control reagent (Applied Biosystems). Conditions and probe and primer sequences for GR, MR, $\mathrm{ENaC} \alpha$, and Sgk-1 mRNA have been previously reported [13]. $\mathrm{Na}, \mathrm{K}-\mathrm{ATP} a \mathrm{se} \alpha 1$ forward probe was used at $900 \mathrm{~nm}$ (GGT GTT GCC CTG AGG ATG TATC), reverse primer at $300 \mathrm{nM}$ (CCG GAC TTC GTC ATA CAC GAA) and probe at $250 \mathrm{nM}$ (TTC TGT GCC TTC CCC TAC TCG CTT CTC ATT); probe and primers were designed from a sequence of the catalytic subunit (sequence corresponding to bp 3181-3273; GI 1205) [33]. 11ß-HSD1 primers and probe were designed using the published sequence of ovine $11 \beta-H S D 1$ (sequence corresponds to bp 664-737 of published sequence) [34]. Forward primer (GGA ATA TGA GGC GAC CAA GGT) and reverse primer (TGG CTG TGT CTG TGT CGA TGA) were used at concentrations of $900 \mathrm{nM}$; TaqMan probe (ATG TGT CAA TCA CCC TCT GTA TTC TT) was used at $250 \mathrm{~nm} .11 \beta$ HSD2 was used as reported by Dodic et al. [35]. Probe and primers were designed using the published ovine sequence for $\beta$-actin (sequence corresponding to bp 878-947; GI 2182268). Forward primer (TTCCTTCCTGGGCATGGA) and reverse primer (GACGTCACACTTCATGATGGATT) were used at concentrations of $900 \mathrm{nM}$; TaqMan probe (TCCTGCGGCATTCACGAAACTACCTT) was used at $250 \mathrm{nM}$.

\section{Immunoblot}

To determine the relative abundance of $\mathrm{ENaC} \alpha, \mathrm{Na}, \mathrm{K}$-ATPase $\alpha 1$ and Sgk-1 proteins, immunoblotting was performed. Samples of lung (lower lobe) and renal cortex from the 80-, 120-, 130-, 145day fetuses and neonates were homogenized and both whole cell and membrane fractions were prepared. Samples from renal medulla at 100, 120,130, 145 days and neonates were similarly prepared. Tissue samples $(0.5-1.0 \mathrm{~g})$ were pulverized over dry ice, and placed in a cold Potter-Elvehjem tissue grinder with 2 vol of ice-cold sucrose buffer ( $1 \mathrm{~mm}$ ethylenediaminetetraacetic acid disodium salt, $0.32 \mathrm{M}$ sucrose, $1 \mathrm{mM}$ ( $N$-[2-hydroxyethyl]piperazine$\mathrm{N}$-[2-ethanesulfonic acid]), $\mathrm{pH} 7.4,1: 100$ protease inhibitor cocktail, Sigma P8340) and homogenized with three up and down strokes. The slurry was spun at $500 \mathrm{~g}, 4^{\circ} \mathrm{C}$ for $5 \mathrm{~min} .300 \mu \mathrm{l}$ of the supernatant was mixed with $300 \mu \mathrm{l} 2 \times$ lysis buffer (4\% sodium dodecyl sulfate, $20 \%$ glycerol, $125 \mathrm{~mm}$ (Tris[hydroxymethyl]aminomethane) $\mathrm{pH}$ 6.8, 5\% 2-mercaptoethanol) and boiled for $5 \mathrm{~min}$. The tubes were spun at $11,300 \mathrm{~g}$ for $5 \mathrm{~min}$ at room temperature. The supernatant was then aliquoted and frozen at $-80^{\circ} \mathrm{C}$ for use for analysis of protein contents in whole cells. The remaining supernatant from the $500 \mathrm{~g}$ spin was spun at $5,000 \mathrm{~g}$ for $5 \mathrm{~min}$ at $4^{\circ} \mathrm{C}$. The supernatant was collected and spun at 45,000 $g$ for $20 \mathrm{~min}$ at $4^{\circ} \mathrm{C}$. The pellet was reconstituted with an equal volume of $2 \times$ lysis buffer. The samples were placed in a warm water bath for $10 \mathrm{~min}$, aliquoted, and stored at $-80^{\circ} \mathrm{C}$ for later analysis of membrane protein contents. Total protein concentrations were determined using the Coomassie protein assay (BioRad, Hercules, Calif., USA) using bovine serum albumin as the standard. The samples were diluted to reduce interference from lysis buffer components and the standards were run with the same lysis buffer concentrations as the samples.

For determination of protein expression by Western blot, optimal sample and antibody concentrations were determined by preliminary experiments using lung whole cell and membrane samples. Specificity of the antibody was confirmed by verification of the appropriate molecular weight for each band (approximately 67 $\mathrm{kDa}$ for $\mathrm{ENaC} \alpha, 100 \mathrm{kDa}$ for $\mathrm{Na}, \mathrm{K}-\mathrm{ATP}$ ase $\alpha 1$, and $54 \mathrm{kDa}$ for Sgk1) and reduction or elimination of the band after preabsorption of the primary antibody using the immunizing peptide. Optimized total protein concentrations were $100 \mu \mathrm{g}$ for lung and renal cortex whole cell preparations and renal cortex membrane preparations, $55 \mu \mathrm{g}$ for renal medulla whole cell preparations, $40 \mu \mathrm{g}$ for renal medullary membrane preparations and $60 \mu \mathrm{g}$ for lung membrane preparations. Samples were run on a either a 7.5\% Tris-polyacrylamide gel $(\mathrm{ENaC} \alpha$ or $\mathrm{Na}, \mathrm{K}-\mathrm{ATP}$ ase $\alpha 1)$ or $10 \%$ Tris-polyacrylamide gel (Sgk-1) of 12, 18 or 26 lanes at $150 \mathrm{~V}$ for approximately $1 \mathrm{~h}$. Lanes containing Bio-Rad Dual Color Standard and a positive control sample were also included on each gel. Sample sets requiring two 12-well gels were run with half of each group on each gel, and were transferred and developed at the same time. All gels were transferred at $100 \mathrm{~V}$ for $1 \mathrm{~h}$ to $0.45-\mu \mathrm{m}$ nitrocellulose membranes. All blots were blocked with a $10 \%$ non-fat dairy milk in Tris-buffered saline Tween-20 solution and exposed to appropriate primary antibodies for the $\alpha$-subunit of ENaC (Abcam, Cambridge, Mass., USA; 3464; 1:100 in blocking solution and 3\% goat serum overnight), primary antibody for the $\alpha 1$-subunit of Na,K-ATPase (Affinity BioReagents, Golden, Colo., USA; MA3-929; 1:10,000 in blocking solution overnight), primary antibody for Sgk-1 (Millipore Corp.) or primary antibody for $\beta$-actin (Sigma, St. Louis, Mo., USA; A-5441; 1:20,000 in blocking solution with 1\% BSA for $1 \mathrm{~h})$. A goat anti-rabbit horseradish peroxidase-conjugated secondary antibody (Sigma A0545; 1:20,000) was used for $\alpha$-ENaC and Sgk-1, and a rabbit anti-mouse horseradish peroxidase-conjugated secondary antibody was used for $\beta$-actin and $\mathrm{Na}, \mathrm{K}$-ATPase (Sigma, A9044; 1:16,000 for $\beta$-actin and 1:2,000 Na,K-ATPase). Immunoreactive proteins were visualized with Amersham ECL detection reagents (GE Healthcare, Piscataway, N.J., USA) and developed with Kodak BioMax XAR film. The blots were analyzed with a Bio-Rad Chemi-Doc system and Quantity One software. The results of the densitometric analysis were then expressed as relative optical density units to $\beta$-actin in the case of lungs. Equal loading of kidney homogenates was verified by staining the blot with India ink in the case of $\mathrm{ENaC} \alpha$, and $\mathrm{Na}, \mathrm{K}$-ATPase $\alpha 1$ blots and Ponceau-S (Sigma) in the case of Sgk-1 blots. 


\section{Statistical Analysis}

Relative expression of each gene in each tissue was analyzed by calculating the threshold cycle number $\left(\mathrm{C}_{t}\right)$, and determining $\Delta C_{t}$ between the mean $C_{t}$ for each gene and the mean $C_{t}$ for $\beta$-actin from the same sample. $\Delta \Delta \mathrm{C}_{\mathrm{t}}$ was calculated as the difference between $\Delta \mathrm{C}_{\mathrm{t}}$ in each sample and the mean $\Delta \mathrm{C}_{\mathrm{t}}$ in the control group. The effect of gestational age on MR, GR and their target genes and corresponding proteins were compared over time by one-way ANOVA using the $\Delta \mathrm{C}_{\mathrm{t}}$ value in the case of gene expression or the relative abundance of protein in the case of the immunoblot results. When data was not normally distributed, the Kruskal-Wallis one-way analysis of variance on ranks was performed. Differences between ages were compared by Duncan's test or Dunn's test, as appropriate. For all statistical tests, $\mathrm{p}<0.05$ was used as the criterion for significance. The fold change in mRNA relative to control was used for graphical purposes and was calculated as $2^{-\Delta \Delta} C_{t}$ using the 80 -day values as the control group for comparison [36].

As an index of relative abundance of genes between tissues, the $\Delta \mathrm{C}_{\mathrm{t}}$ between the mean $\mathrm{C}_{\mathrm{t}}$ for each gene and the mean $\mathrm{C}_{\mathrm{t}}$ for $18 \mathrm{~S}$ was also calculated; mean values of $\Delta \mathrm{Ct}$ for each tissue at each age were calculated from the individual $\Delta \mathrm{Ct}$ in each animal. Relative expression of each gene compared to the expression in lung was

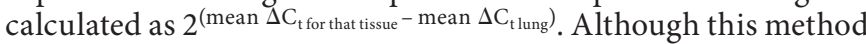
does not quantitatively determine number of ng of mRNA in each tissue, it allows a relative comparison of abundance among tissues as standardized to $18 \mathrm{~S}$ abundance.

\section{Results}

\section{Expression of $G R$ and $M R$}

GR was abundantly expressed in lungs, and renal cortex and medulla. Mean GR mRNA expression relative to $18 \mathrm{~S}$ was approximately 8 -fold greater in lung than in renal cortex, and almost 20 -fold greater than in small intestine at 130 days' gestation, however expression at postnatal day 7 was more similar among tissues (table 1). GR expression in the lung was significantly increased during the second half of fetal life and was significantly higher in fetal lung than in postnatal lung (fig. 1a). In renal cortex, GR expression increased by day 145 , but decreased postnatally (fig. 2a). GR mRNA expression was not significantly different across gestational age in small intestine or renal medulla (fig. 3a, 4a). In contrast, GR expression in small intestine was significantly increased at postnatal day 7 (fig. 4a).

There was also appreciable expression of MR mRNA in lungs and both renal medulla and renal cortex, and lower, but detectable, levels of MR in fetal small intestine. Expression of MR mRNA significantly changed as a function of age in the fetal lung, kidney and small intestine (fig. $1 \mathrm{~b}-4 \mathrm{~b}$ ). In the lung expression of MR was greatest at 130 days, and significantly decreased postnatally
Table 1. Average relative expression of genes in renal cortex, medulla and small intestine as compared to lung at the same developmental age (values are calculated from the mean $\Delta \mathrm{CT}$ compared to $18 \mathrm{~S}$ for the animals in each group)

\begin{tabular}{lcccc}
\hline & Lung & $\begin{array}{c}\text { Renal } \\
\text { cortex }\end{array}$ & $\begin{array}{l}\text { Renal } \\
\text { medulla }\end{array}$ & $\begin{array}{l}\text { Small } \\
\text { intestine }\end{array}$ \\
\hline 130d fetus & & & & \\
MR & 1.0 & 0.14 & 0.14 & 0.01 \\
GR & 1.0 & 0.12 & 0.29 & 0.05 \\
Sgk-1 & 1.0 & 0.19 & 0.66 & 0.26 \\
ENaC $\alpha$ & 1.0 & 1.96 & 5.76 & 0.06 \\
Na,K-ATPase $\alpha 1$ & 1.0 & 0.06 & 0.21 & 0.12 \\
11 $\beta-H S D 1$ & 1.0 & 0.18 & 0.07 & 0.02 \\
11 $\beta-H S D 2$ & 1.0 & 34.0 & 49.7 & 1.33 \\
7d lamb & & & & \\
MR & 1.0 & 1.63 & 1.28 & 0.24 \\
GR & 1.0 & 0.39 & 0.40 & 0.29 \\
Sgk-1 & 1.0 & 0.68 & 0.80 & 0.73 \\
ENaC $\alpha$ & 1.0 & 5.34 & 7.93 & 0.14 \\
Na,K-ATPase $\alpha 1$ & 1.0 & 0.90 & 3.39 & 13.5 \\
11 $\beta-H S D 1$ & 1.0 & 0.29 & 0.18 & 0.11 \\
11 $\beta-H S D 2$ & 1.0 & 13.6 & 52.0 & 0.48 \\
\hline
\end{tabular}

(fig. 1b); mean expression of MR in lung at 130 days relative to $18 \mathrm{~S}$ was approximately 7 -fold greater than in either renal cortex or medulla and 80 -fold higher than in small intestine, whereas levels postnatally were more similar in the various tissues (table 1). As expected, expression of GR was greater in all tissues than expression of MR mRNA, however the ratio of GR to MR mRNA was much less in the lung and renal cortex (7- to 10-fold) than in the renal medulla or small intestine (approximately 20 - and 40 -fold respectively). In the renal medulla there was a modest increase in MR expression after 80 days, whereas in renal cortex there was a small increase only at 130 days of gestation. In small intestine, although there was a significant overall effect of age, and MR expression was greatest on the first postnatal day, this increase was not significant by post-hoc tests (fig. $4 \mathrm{~b}$ ).

\section{Expression of $11 \beta$-HSD1 and $11 \beta-H S D 2$}

Expressions of $11 \beta-\mathrm{HSD} 1$ and $11 \beta-\mathrm{HSD} 2$, the enzymes responsible for conversion of cortisone to cortisol and cortisol to cortisone, respectively, were also tissue-specific in their expression and ontogenetic patterns. Expression of $11 \beta-H S D 1$ appears to be greatest in fetal lung; at 130 days mean expression of $11 \beta$-HSD1 relative to $18 \mathrm{~S}$ was 50 -fold greater in fetal lung than in small intestine and 5 - to 15 -fold greater than in lung than in renal cortex and 


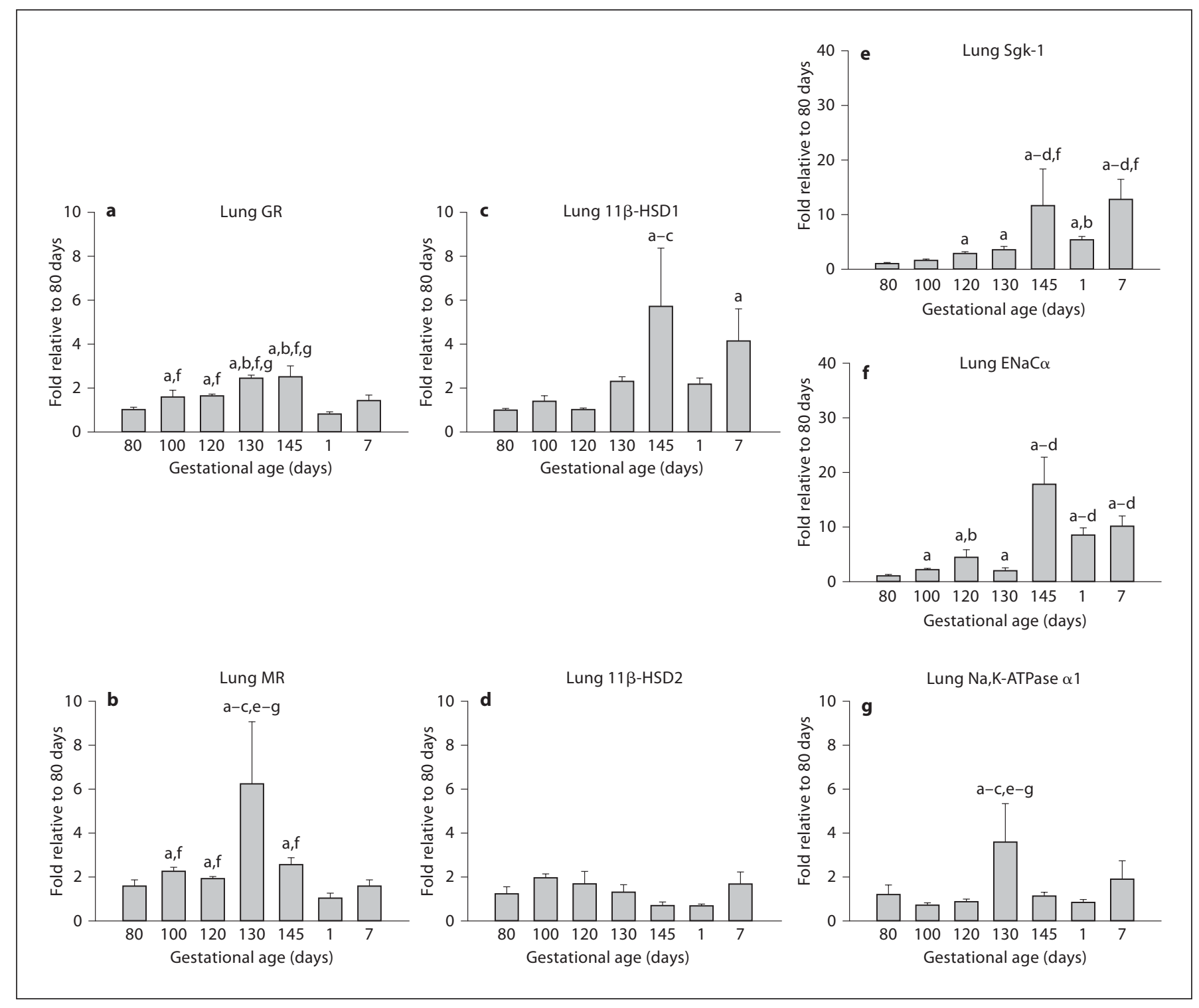

Fig. 1. Expression of glucocorticoid receptor (GR) and mineralocorticoid receptor (MR) and their target genes in lungs of 80-, 100-, 120-, 130- and 145-day fetuses and day 1 and day 7 neonatal lambs. Data are depicted as mRNA fold changes relative to 80 days. (a) GR, (b) MR, (c) 11 $\beta$-hydroxysteroid dehydrogenase 1 (11 $\beta$-HSD1), (d) 11ß-hydroxysteroid dehydrogenase 2 (11ß-HSD2), (e) serum and glucocorticoid-induced kinase (Sgk-1), (f) epithelial sodium channel $(\mathrm{ENaC} \alpha)$, and $(\mathbf{g})$ sodium, potassium ATPase (Na,K-ATPase $\alpha 1)$. Superscripts a-g indicate $\Delta \mathrm{C}_{\mathrm{t}}$ values significantly different by ANOVA: $\mathrm{a}=\mathrm{vs.} 80$ days; $\mathrm{b}=\mathrm{vs} .100$ days; $\mathrm{c}=\mathrm{vs.} 120$ days; $\mathrm{d}=\mathrm{vs}$. 130 days; $\mathrm{e}=$ vs. 145 days; $\mathrm{f}=$ vs. 1 day neonate; $\mathrm{g}=$ vs. 7 days neonate.

medulla (table 1). Conversely, expression of $11 \beta-\mathrm{HSD} 2$ was lowest in fetal lung and small intestine; at 130 days expression of $11 \beta-H S D 2$ relative to $18 \mathrm{~S}$ was 30 - to 50 -fold less in fetal lung than in fetal kidney (table 1). At 130-day expression of $11 \beta$-HSD1 in lung was approximately 6 -fold higher than that of $11 \beta$-HSD2, whereas expression of $11 \beta$-HSD2 was approximately 30 -fold higher in renal cor- tex and 9-fold higher in small intestine than was expression of $11 \beta-H S D 1$. In lung, $11 \beta-H S D 1$ expression was significantly increased from 80 to 130 days (fig. 1c), however there was no change in $11 \beta$-HSD2 expression in late gestation or in the early postnatal period (fig. 1d). In renal cortex, $11 \beta$-HSD2 increased by more than 5 -fold from day 80 to day 100 and remained increased to 7 days postna- 


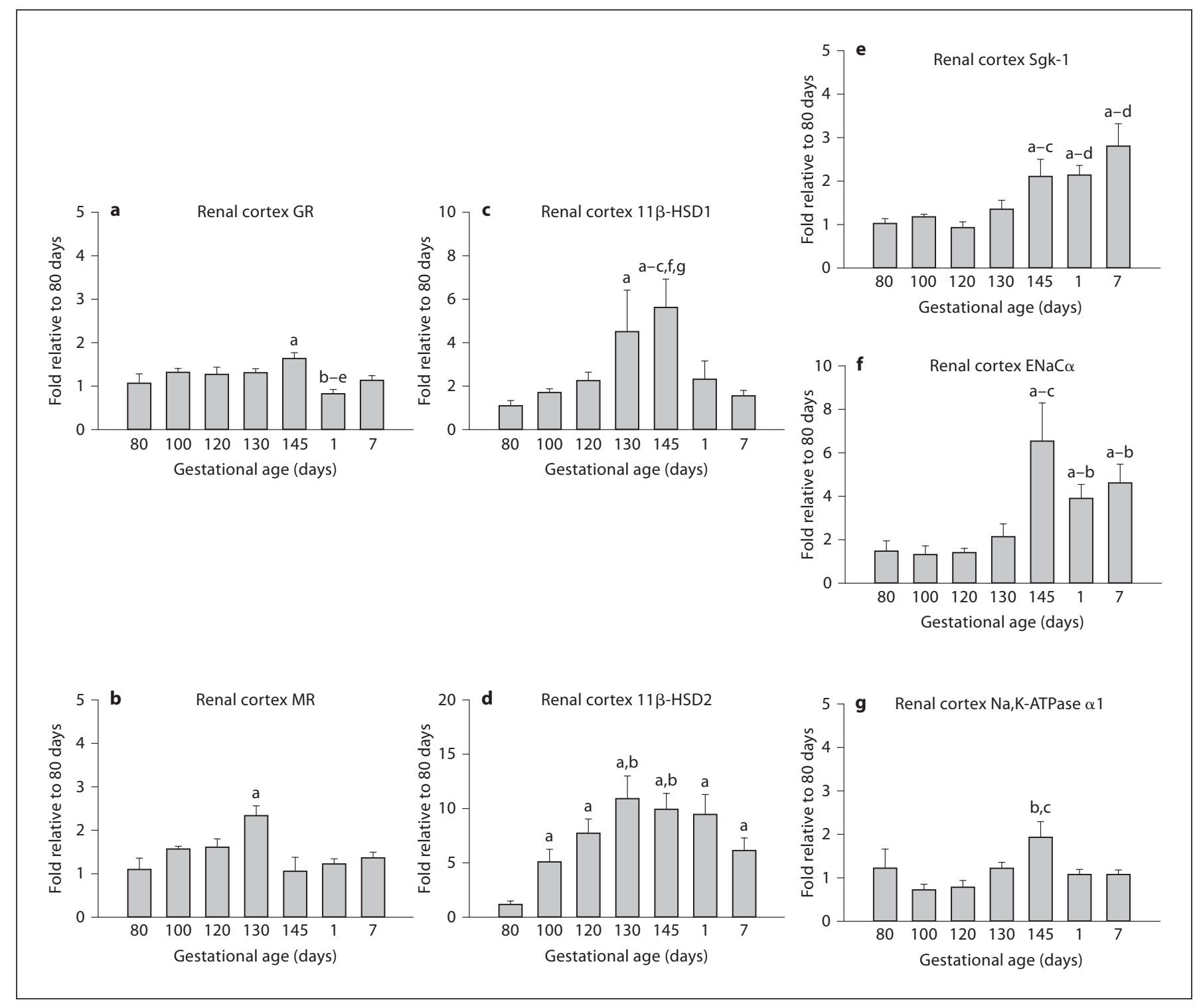

Fig. 2. Expression of MR and GR and their target genes expression in renal cortex of 80-, 100-, 120-, 130- and 145day fetuses and day 1 and day 7 neonatal lambs. Data depicted as mRNA fold changes relative to 80 days. Panels and symbols are as described in figure 1.

tally (fig. 2d). 11ß-HSD1 expression also increases prenatally in renal cortex, but decreased after birth (fig. 2c). In renal medulla, $11 \beta-H S D 1$ did not significantly change, but $11 \beta$-HSD2 dramatically increased prenatally (fig. $3 \mathrm{c}$, d). In intestine there was no increase in $11 \beta$-HSD1 with age, and 11 $\beta$-HSD2 increased near term (fig. $4 \mathrm{c}, \mathrm{d}$ ).

\section{Expression of Sgk-1, ENaC $\alpha$ and $\mathrm{Na}, \mathrm{K}$-ATPase $\alpha 1$}

The pattern of expression of the MR-induced genes was also tissue-specific. Sgk-1 expression was detected at
80 days and increased with gestational age in both lung and kidney. Sgk-1 gene expression was significantly induced in lungs by 120 days gestation and further increased at 145 days, although the magnitude of the increase varied between 3.5- and 38-fold in individual lungs. Sgk-1 mRNA expression remained significantly elevated postnatally, although the magnitude of this increase was also variable among the lambs (fig. 1e). Sgk-1 protein in fetal lungs was significantly increased at days $120-145$ of gestation, and was significantly lower in the 


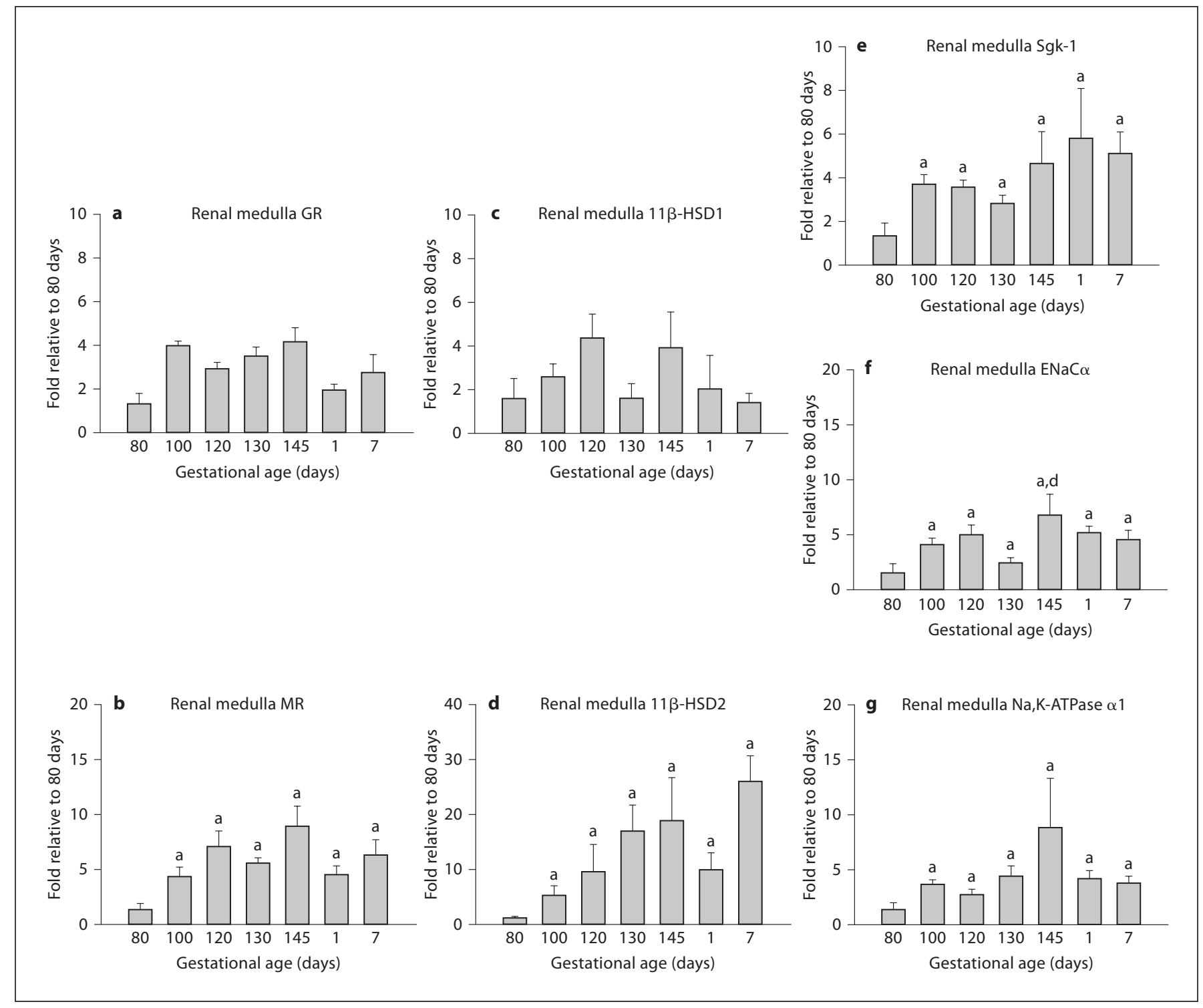

Fig. 3. Expression of MR and GR and their target genes in renal medulla of 80-, 100-, 120-, 130- and 145-day fetuses and day 1 and day 7 neonatal lambs. Data depicted as mRNA fold changes relative to 80 days. Panels and symbols are as described in figure 1.

newborn lamb than in the 120-day lamb (fig. 5e). In contrast, renal cortical expression of Sgk-1 mRNA was not significantly increased until 145 days, and the fold change was much smaller (about 2-fold; fig. 2e). In renal cortex there was no significant change in protein across time, although Sgk-1 protein was greatest in the newborn renal cortex (fig. 6e). In renal medulla, Sgk-1 mRNA increased between 80 and 100 days, but did not increase further with gestational age or postnatally, and there was an increase in Sgk-1 protein at 120 days as compared to 100 days (fig. 7e). Small intestine Sgk1 mRNA increased only postnatally (fig. 4e).

$\mathrm{ENaC} \alpha$ was also expressed in all tissues as early as 80 days of gestation. The relative induction of $\mathrm{ENaC} \alpha \mathrm{mRNA}$ with advancing gestation was also more marked in lungs than in renal medulla or cortex. In lungs the expression of $\mathrm{ENaC} \alpha$ was increased by 100 days; at 145 days the induction was about 18 -fold relative to 80 days (fig. 1f). $\mathrm{ENaC} \alpha$ protein levels were significantly higher in fetal lungs than in the postnatal lung; $\mathrm{ENaC} \alpha$ in lung membrane fraction 


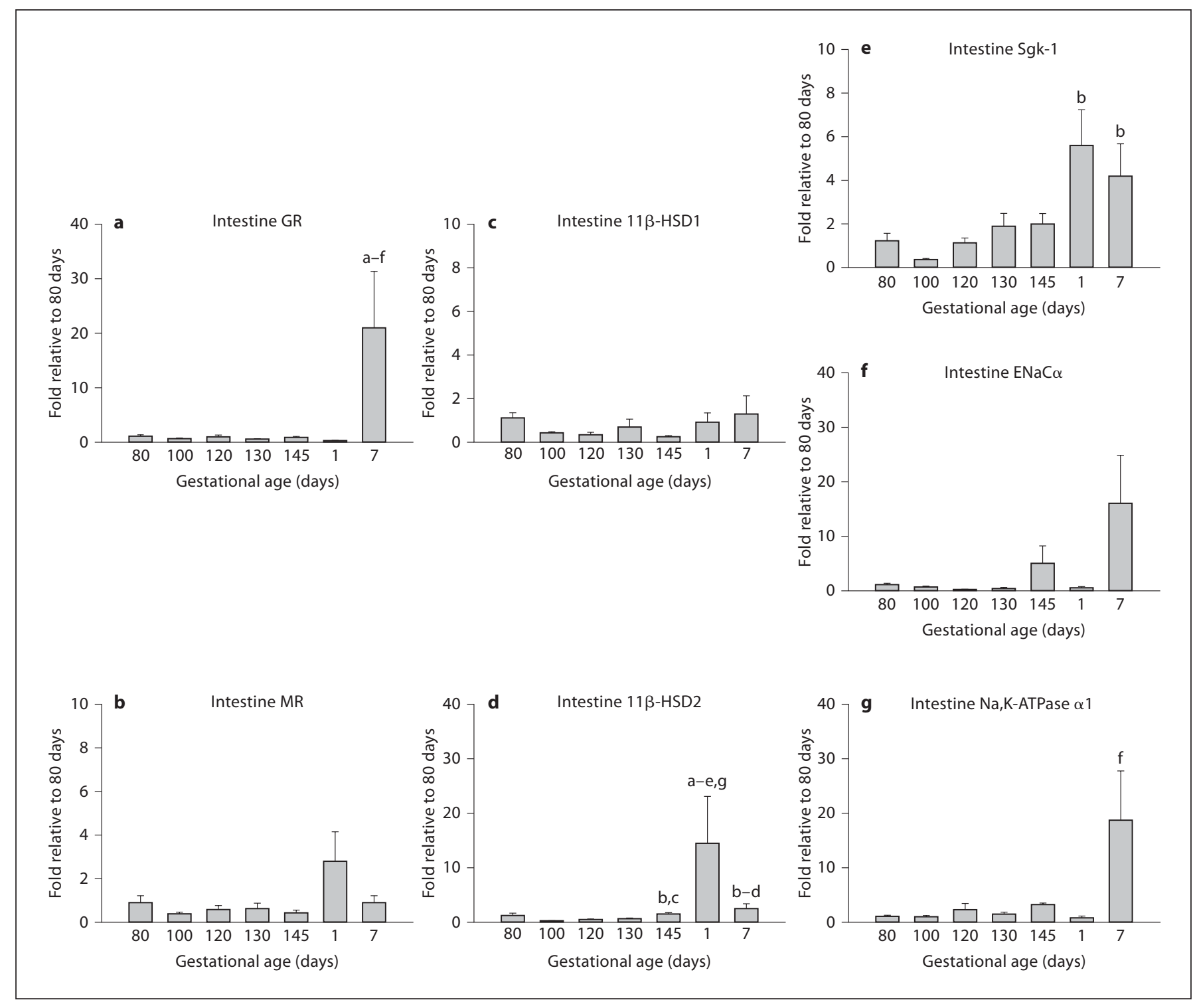

Fig. 4. Expression of MR and GR and their target genes in small intestine of 80-, 100-, 120-, 130- and 145-day fetuses and day 1 and day 7 neonatal lambs. Data depicted as mRNA fold changes relative to 80 days. Panels and symbols are as described in figure 1.

was markedly increased at 130 days, and decreased postnatally (fig. 5a, b). Whole cell $\mathrm{ENaC} \alpha$ protein abundance also decreased postnatally. In kidney, the ontogenetic pattern in expression of ENaC $\alpha$ mRNA was similar to that of Sgk-1 with small increases in mRNA between 80 and 100 days in renal medulla and increases in renal cortex only at 145 days (fig. 2 f, $3 \mathrm{f}$ ). ENaC $\alpha$ protein expression in whole cell extracts of renal cortex decreased from 130 to 145 days, but increased from 145 days to postnatal day 1 . However, $\mathrm{ENaC} \alpha$ protein expression in fractions of renal cortex membrane dramatically increased between 130 and 145 days and remained elevated in the newborn lamb (fig. 6b). In contrast, $\mathrm{ENaC} \alpha$ protein in renal medulla did not show any consistent developmental pattern; $\mathrm{ENaC} \alpha$ in both whole cell and membrane fraction tended to be reduced after 100 days (fig. 7b). In small intestine, ENaC $\alpha$ mRNA expression tended to increase at postnatal day 7, but this increase was variable and not significant (fig. 4f).

$\mathrm{Na}$,K-ATPase $\alpha 1$ mRNA expression in lung was significantly increased at 130 days, but was not significantly in- 


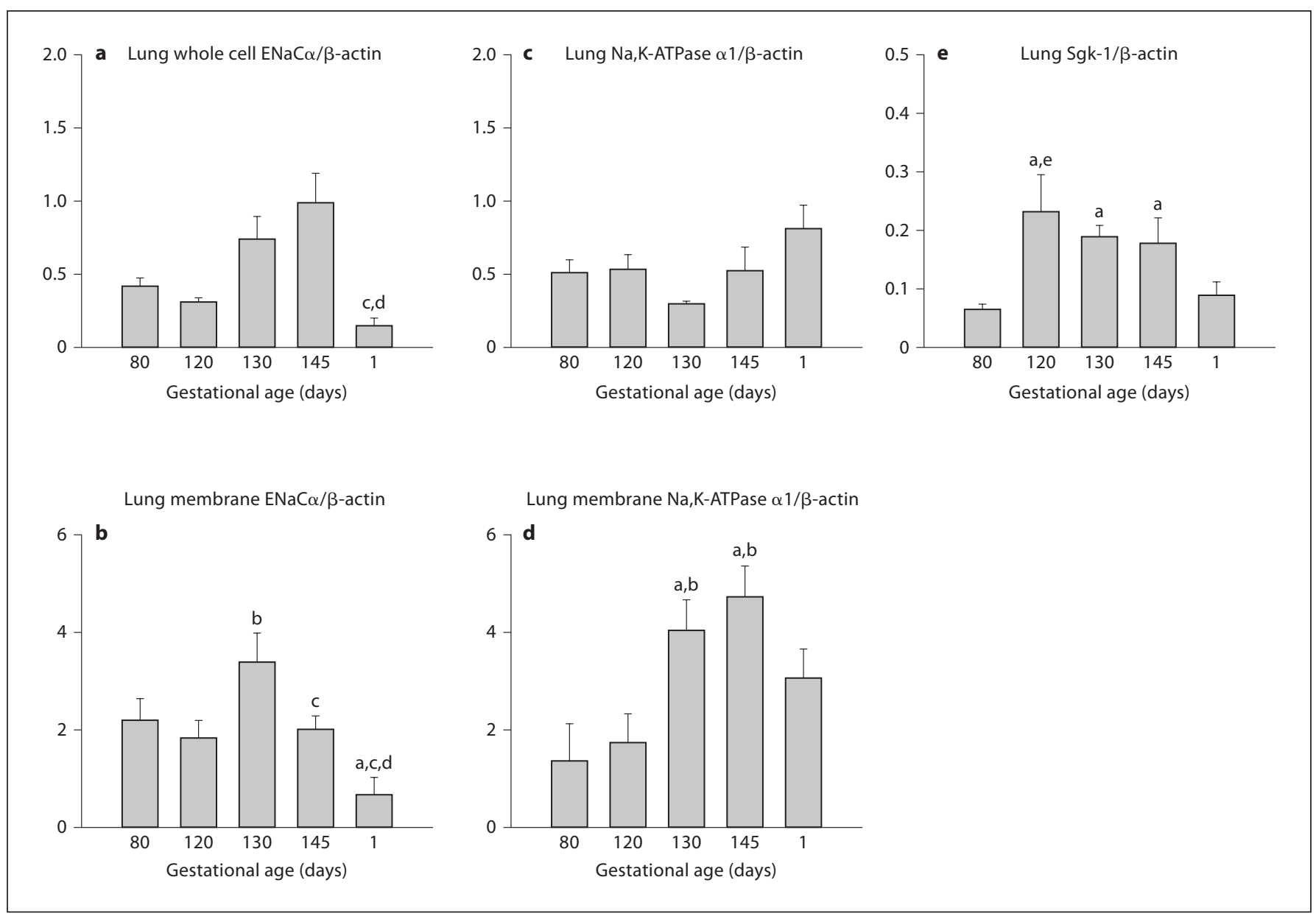

Fig. 5. Abundance of ENaC $\alpha$ protein $(\mathbf{a}, \mathbf{b})$ and $\mathrm{Na}, \mathrm{K}-\mathrm{ATPase}(\mathbf{c}, \mathbf{d})$ and Sgk-1 (e) in homogenates of lung (a, c, e), and in membrane fractions prepared from lung (b, d) of 80-, 120-, 130- and 145-day fetuses and day 1 neonatal lambs. Data are corrected for abundance of $\beta$-actin in the same immunoblot and are expressed in arbitrary units. Superscripts a-e indicate values significantly different by ANOVA: $\mathrm{a}=$ vs. 80 days; $\mathrm{b}=$ vs. 120 days; $\mathrm{c}=$ vs. 130 days; $\mathrm{d}=$ vs. 145 days; $\mathrm{e}=$ vs. 1 day lamb.

creased at later ages (fig. 1g). Na,K-ATPase $\alpha 1$ protein expression in lung was only increased in whole cell extracts from the newborn lungs as compared to lungs of 130-day fetuses, but $\mathrm{Na}$,K-ATPase $\alpha 1$ protein in the membrane fraction was significantly increased at 130-145 days (fig. 5c, d). In renal cortex, $\mathrm{Na}, \mathrm{K}$-ATPase $\alpha 1$ mRNA expression was significantly increased at 145 days (fig. 2g), whereas $\mathrm{Na}, \mathrm{K}$-ATPase $\alpha 1$ protein was decreased at 130 days in whole cell and there was no ontogenetic pattern of change of $\mathrm{Na}, \mathrm{K}$-ATPase $\alpha 1$ protein in membranes from renal cortex (fig. 6d). In renal medulla the increase in Na,K-ATPase $\alpha 1$ mRNA was significant from 100 days of gestation to 7 days postnatally (fig. $3 g$ ). However, Na,K-ATPase $\alpha 1$ protein abundance in whole cell decreased at 145 days relative to 100-day levels and then subsequently increased significantly from 145 days to 1 day; in membrane fractions, $\mathrm{Na}, \mathrm{K}$-ATPase $\alpha 1$ were decreased after 100 days (fig. $7 \mathrm{~d}$ ). In small intestine there was a significant increase in $\mathrm{Na}, \mathrm{K}$-ATPase $\alpha 1$ only in the 7-day lambs (fig. $4 \mathrm{~g}$ ).

\section{Discussion}

The results of this study suggest that lung, kidney and small intestine are all target sites for mineralocorticoid and glucocorticoid action during late gestation and/or at birth. The relatively high abundance of MR in fetal lung previously found in other samples of fetal lung [13] was 


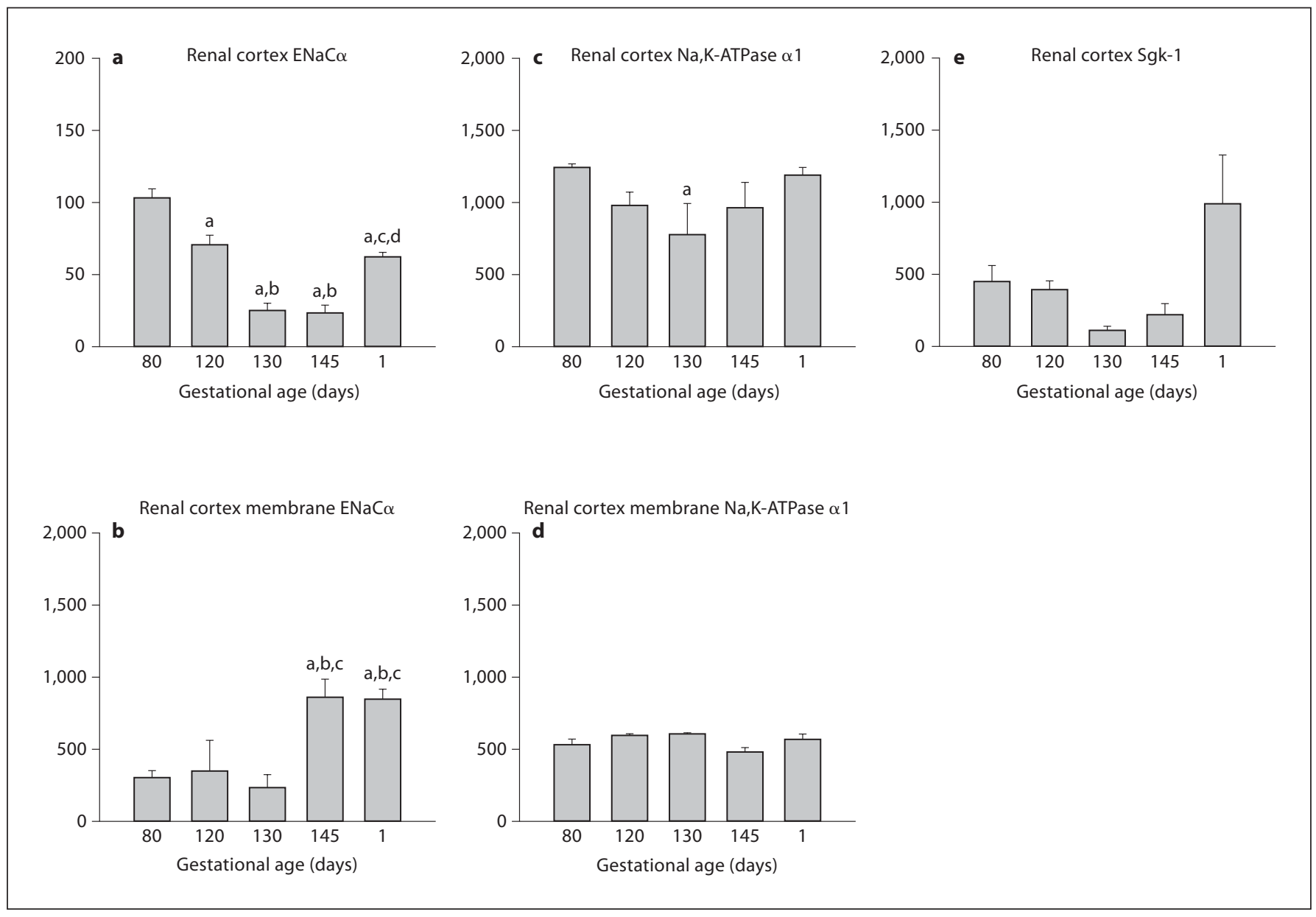

Fig. 6. Abundance of ENaC $\alpha$ protein (a, b), Na,K-ATPase (c, d) and Sgk-1 (e) in homogenates of renal cortex (a, c), and in membrane fractions prepared from renal cortex (b, d) of 80-, 120-, 130 - and 145-day fetuses and day 1 neonatal lambs. Data are expressed in arbitrary units. Superscripts a-d indicate values significantly different by ANOVA: $\mathrm{a}=$ vs. 80 days; $\mathrm{b}=$ vs. 120 days; $\mathrm{c}=$ vs. 130 days; $\mathrm{d}=$ vs. 145 days.

confirmed in this study; we also confirmed the relatively high abundance of $11 \beta$-HSD1 in fetal lung. Consistent with the relatively high level of MR and $11 \beta-H S D 1$ in fetal lung, expression of genes induced by MR in other tissues, including Sgk-1, $\mathrm{ENaC} \alpha$, and $\mathrm{Na}$, K-ATPase $\alpha 1$, and abundance of Sgk1, ENaC $\alpha$ and $\mathrm{Na}$,K-ATPase $\alpha 1$ proteins, were greater in fetal life than in the neonate. Furthermore, the ontogenetic pattern of expression of these corticosteroid responsive genes differed in lung than in the classic epithelial target cells for mineralocorticoid action, the renal cortex, suggesting that corticosteroids may exert earlier actions in the fetal lung than in the kidney.

The relatively high ratio of $11 \beta-H S D 1$ to $11 \beta-H S D 2$ in the lung suggests that cortisol may be the primary ligand at MR and GR in lung, in contrast to renal epithelial cells in which MR are 'protected' by the presence of high levels of $11 \beta$-HSD2. Fetal lung had relatively high expression of $11 \beta$-HSD1, particularly from 130 days of gestation until term, whereas expression of $11 \beta-H S D 2$ was relatively sparse in lung. This result is consistent with the studies of dehydrogenase activity in fetal lung [16]. The results are also consistent with the finding of predominately $11 \beta-H S D 1$ activity in fetal rodent lung [37]. However, studies in human fetal lung explants have suggested the converse: that $11 \beta-\mathrm{HSD} 2$ activity dominates [reviewed in 37] as it does in adult lung. Nonetheless, previous studies did suggest that cortisol conversion to cortisone decreased near term [15], consistent with our finding that $11 \beta-H S D 1$ dramatically increases in late gestation. Relatively low $11 \beta$-HSD2 expression in the late gestation fetal 


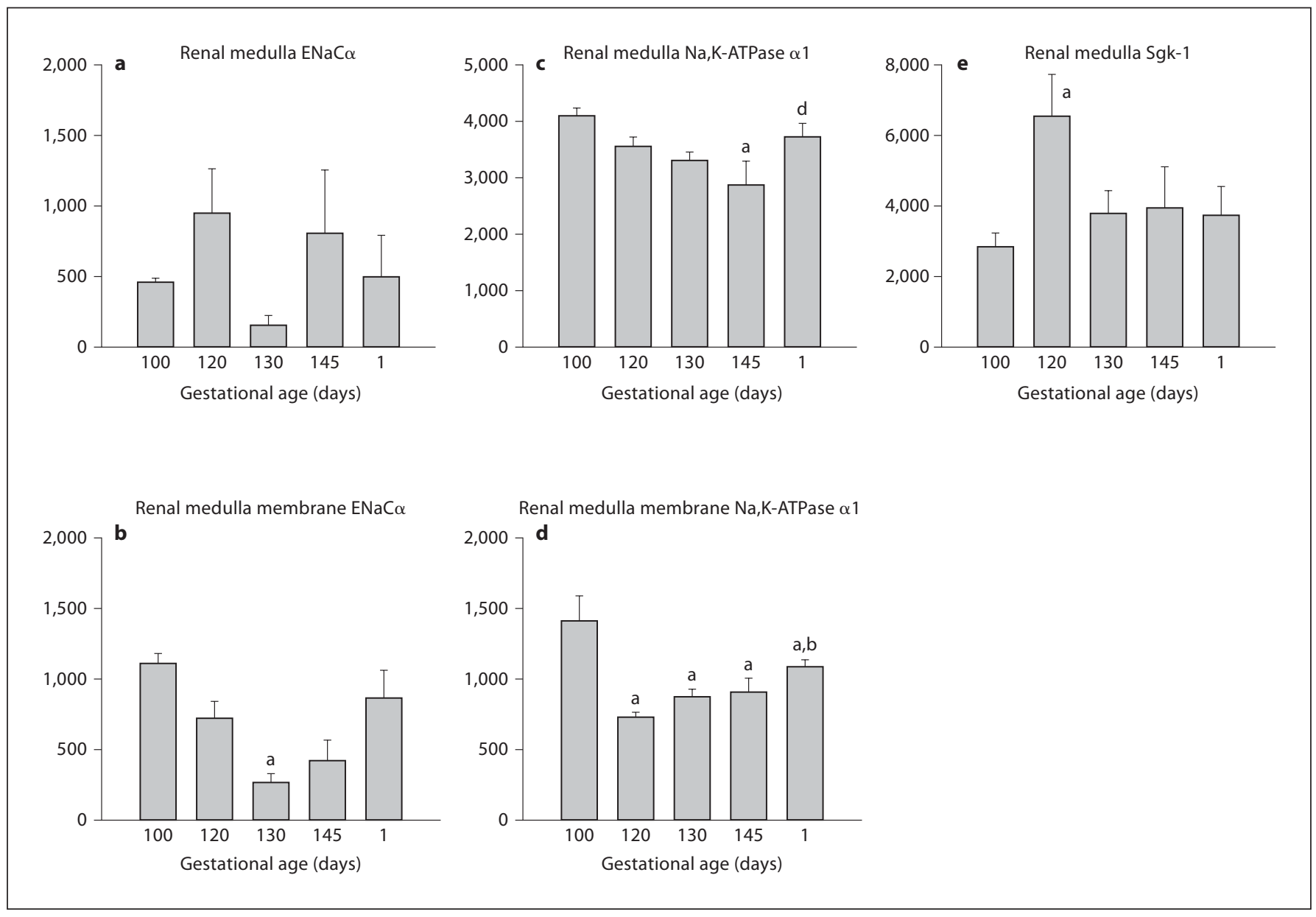

Fig. 7. Abundance of ENaC $\alpha$ protein (a, b), Na,K-ATPase (c, d), and Sgk-1 (e) in homogenates of renal medulla $(\mathbf{a}, \mathbf{c})$, and in membrane fractions prepared from renal medulla (b, d) of 100-, 120-, 130- and 145-day fetuses and day 1 neonatal lambs. Data are expressed in arbitrary units. Superscripts a-d indicate $\Delta \mathrm{C}_{\mathrm{t}}$ values significantly different by ANOVA: $\mathrm{a}=$ vs. 100 days; $\mathrm{b}$ = vs. 120 days; $\mathrm{d}$ = vs. 145 days.

lung would allow binding of circulating cortisol to MR in the fetal lung even in unstressed fetuses before term; free cortisol levels in the ovine fetus at 120-130 days of gestation are estimated to be 1-2 $\mathrm{nM}$, within the range for binding at ovine or human MR (ovine MR: $\mathrm{K}_{\mathrm{i}} 0.2 \mathrm{nM}, \mathrm{K}_{\mathrm{d}}$ $0.5 \mathrm{nM}$ [38]; human MR: $\mathrm{K}_{\mathrm{i}} 0.13 \mathrm{nM}$ [39]). Moreover, fetal cortisol levels are approximately 20 -fold higher than those of aldosterone in the unstressed fetus, suggesting that cortisol is likely to be the sole ligand at MR in $11 \beta$ HSD2 deficient tissues prior to term, except in conditions of fetal hypoxia in which aldosterone would be increased sufficiently to also bind appreciably at MR [40]. In guinea pig fetal lungs, treatment with aldosterone has been shown to significantly decrease the rate of lung fluid production [41], indicating a role of MR in reabsorption in that species. A recent study has suggested that low doses of the natural corticosteroid cortisol are effective at improving oxygen-free survival and reducing the need for dexamethasone when administered to premature newborns [42], underscoring the ability of cortisol to exert effects on the fetal or near term lung. These results therefore suggest that combined MR/GR agonists, such as the endogenous steroid cortisol, may exert greater effects in the lung than would GR agonists alone.

Our study revealed that $\mathrm{ENaC} \alpha, \mathrm{Na}, \mathrm{K}-\mathrm{ATPase} \alpha 1$, and Sgk-1 mRNA levels were significantly increased by day 130 of gestation in the lungs of fetal sheep, with increases in expression of $\mathrm{ENaC} \alpha$ as early as 100 days and Sgk- 1 by 120 days. Expression of Sgk-1 and $\mathrm{ENaC} \alpha$ mRNA peaked at 145 days' gestation and was also relatively high in lung 
at day 1 and day 7 postnatally. Sgk- 1 and $\mathrm{ENaC} \alpha$ proteins were greater in fetal than neonatal lungs; $\mathrm{ENaC} \alpha$ protein in the membrane fraction of lung was most abundant at 130 days, and was significantly reduced in the neonatal lung. Na,K-ATPase mRNA was highest at 130 days' gestation; although whole cell protein was greatest in the newborn, membrane-associated protein was greatest at 130 145 days. These results are consistent with corticosteroidmediated effects in epithelium. The amiloride-sensitive $\mathrm{ENaC}$ is found in the apical membrane of salt-absorbing epithelia lining the lungs as well as in the distal nephron and the distal colon, and constitutes the rate-limiting step in the transepithelial sodium absorption [43]. In adult kidneys, ENaC mRNA and protein are regulated by aldosterone, and acute changes in aldosterone increase $\mathrm{ENaC}$ activity and membrane localization of $\mathrm{ENaC} \alpha$ by reducing degradation of the channel [19]. Studies suggest that both $\mathrm{ENaC} \alpha$ and $\mathrm{Na}, \mathrm{K}-\mathrm{ATPase} \alpha 1$ are involved in lung liquid reabsorption at term (reviewed by Barker and Olver [44]). In utero, secretion of lung liquid contributes to amniotic fluid; at term ENaC plays an important role in the transition from active secretion of fluid to net reabsorption in order to allow oxygen diffusion postnatally. The $\alpha$-subunit of $\mathrm{ENaC}$ appears to be critical for action of this ion channel at birth; mice with knockouts of the $\alpha$-subunits of $\mathrm{ENaC}$, but not $\beta$ - or $\gamma$-subunits, die within 2 days of birth because of the inability to reabsorb lung fluid, resulting in severe neonatal respiratory distress [20]. Recent data have shown that expression of Sgk-1 is decreased in lung of human fetuses with exposure to chorioamnionitis [45]; they suggest that inflammation may reduce Sgk-1 effects on ENaC localization and therefore lead to the increased risk of respiratory distress syndrome.

In addition to the well-known critical action of glucocorticoids in regulating pulmonary development and surfactant production, glucocorticoids have been implicated in this increase in lung $\mathrm{ENaC} \alpha$ expression and function [46]. Previous studies have found that corticosteroids increase expression of $\mathrm{ENaC}$, and that adrenal steroids also increase $\mathrm{Na}, \mathrm{K}-\mathrm{ATPa}$ e expression in lung, although the latter effect appears to also require the increase in $\mathrm{PO}_{2}$ levels which occurs at term [44]. However, our results show that both $\mathrm{ENaC} \alpha$ and $\mathrm{Na}$,K-ATPase $\alpha 1$ mRNAs significantly increase in lung before delivery, by day 130 of gestation. Sgk-1, ENaC $\alpha$ and $\mathrm{Na}, \mathrm{K}-\mathrm{ATP}$ ase $\alpha 1$ proteins in lung membranes are also high as early as 130 days of gestation, before appreciable increases in fetal adrenal cortisol secretion which would activate GR. Thus, the relatively high expression of $11 \beta-H S D 1$ and MR, and the changes in Sgk-1, $\mathrm{ENaC} \alpha$, and $\mathrm{Na}, \mathrm{K}-\mathrm{ATPase} \alpha 1$ in the preterm fe- tus suggest that adrenal steroids may act via MR even when fetal plasma corticosteroid levels are relatively low. This suggests that changes in cortisol and/or aldosterone in the late gestation fetus may have important physiologic actions to alter the molecular machinery critical for determining the rate of lung liquid production.

In an earlier study in our laboratory, we found that reduction of maternal corticosteroid levels, which reduces amniotic fluid, reduced lung liquid secretion rate at 130 days [47]. We have hypothesized that this effect was a homeostatic response in the fetus to regulate fetal volume and occurred secondary to the increase in fetal aldosterone which we measured. However, studies by Wallace et al. $[48,49]$ have found that fetal adrenalectomy in late gestation causes a reduction in lung liquid secretion, whereas fetal cortisol infusion increases lung liquid production; it is not clear in these studies if this was a direct effect of cortisol or secondary to other changes. The present results are consistent with the hypothesis that changes in fetal cortisol directly effect sodium reabsorption.

Studies from other laboratories have shown that the fetal sheep kidney expresses MR and GR, although at lower mRNA levels than in adult kidney [50]. The earlier increase in expression of these receptors in fetal sheep relative to rodent species is not surprising, as nephron development in sheep occurs prenatally, rather than postnatally as in rodent species [51]. Nonetheless, the kidney of the ovine fetus is relatively unresponsive to aldosterone. Changes in urinary sodium and potassium secretion do occur in response to aldosterone, however the infusion rates used produced aldosterone levels well above the low levels of plasma aldosterone found in normal, unstressed fetuses of less than 130 days [52]. Other studies have shown that the fetal secretion of corticosteroids does not play a major role before 139 days [53], but that the increase in urinary to plasma $\mathrm{Na} / \mathrm{K}$ ratio with age in late gestation sheep correlates with the increase in aldosterone as the fetal adrenal matures [54]. Our results confirm the presence of MR and GR in fetal renal cortex and medulla, and also relatively high expression of $11 \beta-$ HSD2 expression in renal cortex. We also found induction of Sgk-1, ENaC $\alpha$ and $\mathrm{Na}, \mathrm{K}-\mathrm{ATPase} \alpha 1$ in the renal cortex by 145 days of gestation and postnatally. Although we found no change in whole cell proteins, membranelocalized $\mathrm{ENaC} \alpha$ was increased in renal cortex by 145 days. These data are consistent with MR-mediated effects at term as fetal adrenal aldosterone secretion increases. In contrast, in the renal medulla there was an increase in expression of all genes between 80 and 100 days of gestation, but few changes occurred after that 
age, and protein expression tended to decrease after 100 days. In the sheep metanephros, nephrogenesis is complete by $120-130$ days' gestation, and the increase in expression of several of the studied genes in medulla between 80 and 100 days occurs at the time of maximal nephrogenesis, during which the nephrons migrate from inner to outer zones of the developing kidney [55]. This suggests the increase in gene expression parallels differentiation of cells in the medulla.

Our study revealed statistically significant postnatal increases in Sgk-1 and Na,K-ATPase in small intestine. Our data are consistent with GR-mediated effects stimulated by the relatively high levels of cortisol which occur at term. Whereas aldosterone action at MR is hypothesized to be an important regulator of sodium transport in the neonatal colon in the immature small intestine, dehydrogenase activity is low compared to that of colon, suggesting effects of cortisol at MR or GR would predominate because of the higher concentrations of cortisol relative to aldosterone [22]. In our studies, expression of $11 \beta-H S D 1$ and $11 \beta-H S D 2$ were both relatively low in prenatal small intestine, consistent with possible effects of cortisol. However, the relatively low MR expression in small intestine would be consistent with GR-mediated effects of cortisol as fetal adrenal cortisol secretion increases at term.

In summary, our data show that MR expression and corticosteroid-induced genes in renal cortex increase only in the late gestation; this is consistent with increased aldosterone effects on the kidneys near term. In small intestine the induction also occurs at term, but are most likely GR-mediated. However, increases in expression of MR and corticosteroid-induced genes occurred in the lung earlier in fetal life. Further, the increase in expression of Sgk-1, $\mathrm{ENaC} \alpha$, and $\mathrm{Na}, \mathrm{K}-\mathrm{ATP}$ ase $\alpha 1 \mathrm{mRNA}$ and in Sgk- 1 and lung membrane $\mathrm{ENaC} \alpha$, and $\mathrm{Na}$,K-ATPase $\alpha 1$ protein between 120 and 130 days indicate that there is an increase in corticoid action which is disproportionate relative to the rather small increases in fetal plasma cortisol that occur over this time in gestation. The increases in corticosteroid-regulated genes appear to be related to the increase in MR and 11ß-HSD1 expression occurring between 120 and 130 days. There are several important implications suggested by these finding: (1) that increasing concentrations of circulating corticosteroids of either maternal or fetal origin may be important in the regulation of lung liquid secretion and/or reabsorption as early as 120-130 days of gestation, and may contribute to normal fetal fluid homeostasis and changes in production of amniotic fluid with maternal or fetal stress; (2) that the normal transition to extrauterine life may involve coordinated action of cortisol on MR as well as GRmediated target genes, and (3) therapies that result in activation of MR as well as GR may be more effective in producing reabsorption of fluid in preterm infants.

\section{Acknowledgements}

We would like to thank Xiaoyang (Lisa) Fang and Krista Koehler for their technical assistance in these studies. This study was supported by NIH grant DK62080.

\section{References}

1 Liggins GC, Fairclough RJ, Grieves SA, Kendall JZ, Knox BS: The mechanism of initiation of parturition in the ewe. Recent Prog Horm Res 1973;29:111-159.

$\longrightarrow 2$ Liggins GC, Fairclough RJ, Grieves SA, Forster CS, Knox BS: Parturition in the sheep. Ciba Found Symp 1977;47:5-30.

-3 Ballard PL, Ertsey R, Gonzales LW, Gonzales J: Transcriptional regulation of human pulmonary surfactant proteins SP-B and SP-C by glucocorticoids. Am J Respir Cell Mol Biol 1996; 14:599-607.

-4 Liggins GC, Howie RN: A controlled trial of antepartum glucocorticoid treatment for prevention of the respiratory distress syndrome in premature infants. Pediatrics 1972; 50:515-525

5 Fowden AL, Mijovic J, Silver M: The effects of cortisol on hepatic and renal gluconeogenic enzyme activities in the sheep fetus during late gestation. J Endocrinol 1993;137:213-222.
6 Fowden AL, Apatu RS, Silver M: The glucogenic capacity of the fetal pig: developmental regulation by cortisol. Exp Physiol 1995;80: 457-467.

7 Arsenault P, Menard D: Influence of hydrocortisone on human fetal small intestine in organ culture. J Pediatr Gastroenterol Nutr 1985;4:893-901.

8 Galand G: Brush border membrane sucraseisomaltase, maltase-glucoamylase and trehalase in mammals. Comparative development, effects of glucocorticoids, molecular mechanisms, and phylogenetic implications. Comp Biochem Physiol B 1989;94:1-11.

$\checkmark 9$ Hennessy DP, Coghlan JP, Hardy KJ, Scoggins BA, Wintour EM: The origin of cortisol in the blood of fetal sheep. J Endocrinol 1982; 95:71-79.

10 McMullen S, Osgerby JC, Thurston LM, Gadd TS, Wood PJ, Wathes DC, Michael AE: Alterations in placental $11 \beta$-hydroxysteroid dehydrogenase (11 $\beta-H S D)$ activities and fetal cortisol:cortisone ratios induced by nutritional restriction prior to conception and at defined stages of gestation in ewes. Reproduction 2004;127:717-725.

11 Diaz R, Brown RW, Seckl JR: Distinct ontogeny of glucocorticoid and mineralocorticoid receptor and $11 \beta$-hydroxysteroid dehydrogenase types I and II mRNAs in the fetal rat brain suggest a complex control of glucocorticoid actions. J Neurosci 1998;18:2570-2580.

12 Condon J, Gosden C, Gardener D, Nickson P, Hewison M, Howie AJ, Stewart PM: Expression of type $211 \beta$-hydroxysteroid dehydrogenase and corticosteroid hormone receptors in early human fetal life. J Clin Endocrinol Metab 1998;83:4490-4497.

13 Keller-Wood M, Wood CE, Hua Y, Zhang D: Mineralocorticoid receptor expression in late-gestation ovine fetal lung. J Soc Gynecol Investig 2005;12:84-91. 
-14 Edwards CR, Benediktsson R, Lindsay RS, Seckl JR: 11 $\beta$-Hydroxysteroid dehydrogenases: key enzymes in determining tissuespecific glucocorticoid effects. Steroids 1996; 61:263-269.

15 Murphy BEP: Ontogeny of cortisol-cortisone interconversion in human tissues: a role for cortisone in human fetal development. J Steroid Biochem 1981;14:811-817.

$\checkmark 16$ Wood CE, Srun R: Ontogeny of $11 \beta$-hydroxysteroid dehydrogenase in ovine fetal kidney and lung. Reprod Fertil Dev 1995;7: 1329-1332.

-17 Hundertmark S, Dill A, Buhler H, Stevens P, Looman K, Ragosch V, Seckl JR, Lipka C: $11 \beta$-Hydroxysteroid dehydrogenase type 1 : a new regulator of fetal lung maturation. Horm Metab Res 2002;34:537-544.

18 Funder JW: Corticosteorid receptors and renal $11 \beta$-hydroxysteroid dehydrogenase activity. Semin Nephrol 1990;10:311-319.

19 Verrey F, Loffing J, Zecevic M, Heitzmann D, Staub O: Sgk1: aldosterone-induced relay of $\mathrm{Na}^{+}$transport regulation in distal kidney nephron cells. Cell Physiol Biochem 2003;13: 21-28.

20 Hummler E, Barker P, Gatzy J, Beermann F, Verdumo C, Schmidt A, Boucher R, Rossier BC: Early death due to defective neonatal lung liquid clearance in $\alpha$-ENaC-deficient mice. Nat Genet 1996;12:325-328.

-21 Olver RE, Walters DV, Wilson M: Developmental regulation of lung liquid transport. Annu Rev Physiol 2004;66:77-101.

-22 Pacha J, Miksik I, Mrnka L, Zemanova Z, Bryndova J, Mazancova K, Kucka M: Corticosteroid regulation of colonic ion transport during postnatal development: methods for corticosteroid analysis. Physiol Res 2004; 53(suppl 1):S63-S80.

-23 Dagenais A, Denis C, Vives MF, Girouard S, Masse C, Nguyen T, Yamagata T, Grygorczyk C, Kothary R, Berthiaume Y: Modulation of $\alpha-\mathrm{ENaC}$ and $\alpha 1-\mathrm{Na}^{+}-\mathrm{K}^{+}-\mathrm{ATPase}$ by cAMP and dexamethasone in alveolar epithelial cells. Am J Physiol 2001;281:L217-L230.

-24 Mustafa SB, DiGeronimo RJ, Petershack JA, Alcorn JL, Seidner SR: Postnatal glucocorticoids induce $\alpha$-ENaC formation and regulate glucocorticoid receptors in the preterm rabbit lung. Am J Physiol 2004;286:L73-L80.

25 Venkatesh VC, Katzberg HD: Glucocorticoid regulation of epithelial sodium channel genes in human fetal lung. Am J Physiol 1997;273:L227-L233.

-26 Nakamura K, Stokes JB, McCray PB Jr: Endogenous and exogenous glucocorticoid regulation of ENaC mRNA expression in developing kidney and lung. Am J Physiol 2002; 283:C762-C772.

-27 Itani OA, Auerbach SD, Husted RF, Volk KA, Ageloff S, Knepper MA, Stokes JB, Thomas CP: Glucocorticoid-stimulated lung epithelial $\mathrm{Na}^{+}$transport is associated with regulated $\mathrm{ENaC}$ and Sgk1 expression. Am J Physiol 2002;282:L631-L641.
28 Tchepichev S, Ueda J, Canessa C, Rossier BC, O’Brodovich H: Lung epithelial Na channel subunits are differentially regulated during development and by steroids. Am J Physiol 1995;269:C805-C812.

29 Dagenais A, Denis C, Vives MF, Girouard S, Masse C, Nguyen T, Yamagata T, Grygorczyk C, Kothary R, Berthiaume Y: Modulation of $\alpha-\mathrm{ENaC}$ and $\alpha 1-\mathrm{Na}^{+}-\mathrm{K}^{+}$-ATPase by cAMP and dexamethasone in alveolar epithelia cells. Am J Physiol 2001;281:L217-L230.

30 Chalaka S, Ingbar DH, Sharma R, Zhau Z, Wendt $\mathrm{CH}$ : $\mathrm{Na}^{+}-\mathrm{K}^{+}$-ATPase gene regulation by glucocorticoids in a fetal lung epithelial cell line. Am J Physiol 1999;277:L197-L203.

31 Kolla V, Robertson NM, Litwack G: Identification of a mineralocorticoid/glucocorticoid response element in the human $\mathrm{Na} / \mathrm{K}$ ATPase $\alpha 1$ gene promoter. Biochem Biophys Res Commun 1999;266:5-14.

32 Mick VE, Itani OA, Loftus RW, Husted RF, Schmidt TJ, Thomas CP: The $\alpha$-subunit of the epithelial sodium channel is an aldosterone-induced transcript in mammalian collecting ducts, and this transcriptional response is mediated via distinct cis-elements in the $5^{\prime}$-flanking region of the gene. Mol Endocrinol 2001;15:575-588.

-33 Shull GE, Schwartz A, Lingrel JB: Aminoacid sequence of the catalytic subunit of the $\left(\mathrm{Na}^{+}+\mathrm{K}^{+}\right)$ATPase deduced from a complementary DNA. Nature 1985;316:691-695.

\34 Yang K, Smith CL, Dales D, Hammond GL, Challis JRG: Cloning of an ovine 11ß-hydroxysteroid dehydrogenase complementary deoxyribonucleic acid: tissue and temporal distribution of its messenger ribonucleic acid during fetal and neonatal development. Endocrinology 1992;131:2120-2126.

35 Dodic M, Abouantoun T, O'Connor A, Wintour EM, Moritz KM: Programming effects of short prenatal exposure to dexamethasone in sheep. Hypertension 2002;40:729-734.

-36 Livak KJ, Schmittgen TD: Analysis of relative gene expression data using real-time quantitative PCR and the 2(Delta Delta C(T)) method. Methods 2001;25:402-408.

37 Garbrecht MR, Klein JM, Schmidt TJ, Snyder JM: Glucocorticoid metabolism in the human fetal lung: implications for lung development and the pulmonary surfactant system. Biol Neonate 2006;89:109-119.

38 Richards EM, Hua Y, Keller-Wood M: Pharmacology and physiology of ovine corticosteroid receptors. Neuroendocrinology 2003; 77:2-14.

39 Rupprecht R, Reul JM, van Steensel B Spengler D, Soder M, Berning B, Holsboer F, Damm K: Pharmacological and functional characterization of human mineralocorticoid and glucocorticoid receptor ligands. Eur J Pharmacol 1993;247:145-154.

40 Robillard JE, Ayres AN, Bomez RA, Nakamura KT, Smith FG Jr: Factors controlling aldosterone secretion during hypoxemia in fetal lambs. Pediatr Res 1984;18:607-611.
41 Kindler PM, Chaung DC, Perks AM: Fluid production by in vitro lungs from near-term fetal guinea pigs: effects of cortisol and aldosterone. Acta Endocrinol 1993;129:169-177.

42 Bonsante F, Latorre G, Iacobelli S, Forziati V, Laforgia N, Esposito L, Mautone A: Early low-dose hydrocortisone in very preterm infants: a randomized, placebo-controlled trial. Neonatology 2007;91:217-221.

$>43$ Kellenberger S, Schild L: Epithelial sodium channel/degenerin family of ion channels: a variety of functions for a shared structure. Physiol Rev 2002;82:735-767.

44 Barker PM, Olver RE: Invited review: clearance of lung liquid during the perinatal period. J Appl Physiol 2002;93:1542-1548.

45 Wirbelauer J, Schmidt B, Klingel K, Cao L, Lang F, Speer CP: Serum and glucocorticoidinducible kinase in pulmonary tissue of preterm fetuses exposed to chorioamnionitis. Neonatology 2007;93:257-262.

46 Bolt RJ, van Weissenbruch MM, Lafeber HN, Delemarre-van de Waal HA: Glucocorticoids and lung development in the fetus and preterm infant. Pediatr Pulmonol 2001;32: $76-91$.

47 Jensen E, Wood CE, Keller-Wood M: Alterations in maternal corticosteroid levels influence fetal urine and lung liquid production. J Soc Gynecol Investig 2003;10:480-489.

$\checkmark 48$ Wallace MJ, Hooper SB, Harding R: Effects of elevated fetal cortisol concentrations on the volume, secretion, and reabsorption of lung liquid. Am J Physiol 1995;269:R881-R887.

49 Wallace MJ, Hooper SB, Harding R: Role of the adrenal glands in the maturation of lung liquid secretory mechanisms in fetal sheep. Am J Physiol 1996;270:R33-R40.

50 Hantzis V, Albiston A, Matsacos D, Wintour EM, Peers A, Koukoulas I, Myles K, Moritz K, Dodic M: Effect of early glucocorticoid treatment on MR and GR in late gestation ovine kidney. Kidney Int 2002;61:405-413.

51 Moritz KM, Boon WC, Wintour EM: Aldosterone secretion by the mid-gestation ovine fetus: role of the AT2 receptor. Mol Cell Endocrinol 1999;157:153-160.

52 Robillard JE, Nakamura KT, Lawton WJ: Effects of aldosterone on urinary kallikrein and sodium excretion during fetal life. Pediatr Res 1985;19:1048-1052.

53 Benson CA, Wintour EM: The effect of bilateral fetal adrenalectomy on fluid balance in the ovine fetus [erratum appears in J Physiol (Lond) 1996;491:889]. J Physiol (Lond) 1995; 489:235-241.

54 Robillard JE, Ramberg E, Sessions C, Consamus B, Van Orden D, Weismann D, Smith FG Jr: Role of aldosterone on renal sodium and potassium excretion during fetal life and newborn period. Dev Pharmacol Ther 1980; 1:201-216.

55 Gimonet V, Bussieres L, Medjebeur AA, Gasser B, Lelongt B, Laborde K: Nephrogenesis and angiotensin II receptor subtypes gene expression in the fetal lamb. Am J Physiol 1998;274:F1062-F1069. 